\title{
CULTURAL CONFLICT REFLECTED FROM “IN THE SKIN OF A LION” BY MICHAEL ONDAATJE
}

\section{Dr Om P Joshi}

\begin{abstract}
"Diaspora" and "migration" are integrated two terms. Term 'immigration' denotes the departure from the home and native for getting betterment or elsewhere reason. After settled in the host land the immigrants are suffering for the homesickness, dislocation, seeking own identities in multiple cultures and here the diasporic writer tries to negotiate the situation. In diaspora there is a constant debate about homelessness, and the agony of being located and then dislocated. Migrant writers are keen to trace their roots and write about the social, political as well as cultural happenings of their native homelands. As the immigrant settled in the other nation he is longing from the native culture. And in such situation there outcomes the cultural conflicts and cultural hybridity. Here in this paper I have poured my skill to justify the Michael Ondaatje's novel "In the skin of a lion" with the cultural conflict point of view.
\end{abstract}

Key words:- Diaspora, Cultural conflict

\section{Diaspora}

Before glance over the cultural conflict, it is necessary to understand the term "diaspora" and its effect on the migrants. The term 'Diaspora' is most chewed field in literature. Basically the term "diaspora" is derived from the Greek word diaspeirein. 'dia' stands for 'across' and 'speirein' stands for 'scatter'. Whereas the same term used by English language to present the concept of moving the group of people who have the common ethnic identity or forced to move of their own accord. Term diaspora was initially launched in the Bible in Deuteronomy 28:25 "thou shalt be a dispersion in all kingdoms of the earth". Diaspora has also an ancient history with the Jewish people as they were moving from one to other country for seeking the home and rest and finally after two thousand years they were settled in Isreal around 1948 
when state became in existence. They had to disperse to several countries and had to survive against political persecution engendering from racial discrimination. The history is fall of the racial persecution of the Jews by the gentiles and this persecution culminated in holocaust - an attempt to exterminate the Jews from the face of the earth. This was known as the Jewish Diaspora.

Another mass outflow took place when the blackish Africans were exported to the West as labourers and slavers. This homelessness was committed forcefully with the mean purpose of Britishers. But after the Second World War, the concept of migration had changed its colour and immigration became voluntary and a global phenomenon. Around 1950's the term 'diaspora' came into use by English language for the number of people left own nation to settle in foreign countries. The migrants are settled in the host land with the memories, culture and ethics of the native land. And here they are trying to settle with confliction between the cultures. And if any migrant meets other pre-settled migrants, he feels them as family members. This kind of situation is nicely presented by Anita Rau Badami in her disporic novel "Can You Hear the Nightbird Call?"

\section{Diaspora - Cultural Conflict \& Cultural Hybridity}

The term 'culture' is applied for the integral part of the human knowledge, behaviour and beliefs that depends upon the capacity for learning and transmitting knowledge to succeeding generations. Thus the culture is gifted from the womb of the mother. And here the cultural conflict arose when different cultures become head-to-head and tries to prove own culture much important than others with strong religious beliefs and values.

According to M.Sagaya "Cultural conflict is the processes and the resulting guilt of fleeing a restrictive background of tradition."

Whereas Jonathan $\mathrm{H}$. Turner says "Cultural conflict is a result of difference in cultural values and beliefs which puts people in odd situation with one another"

There are many similarity and differences in the people around us. They are homogeneous when they all have the similarities and sharing the common characteristics. And at the same time they are heterogeneous as they have the 
differences with the birth place, dialects, brought up in various atmosphere and culture; even they have the different set of beliefs and values. In the cross culture migration, there are so many issues and this one is the prime goal of diaspora to find out the issues and to solve them. Country with the concept of secularism, there are dwelling more than one group of people with having the diversity in the culture. And meanwhile there we can see the cultural conflict. So here cultural conflict is a type of conflict which happens when clashing the various cultural values and beliefs. Cultural conflicts are common at the society with multiculturalism and secularism as different social group has the different beliefs and ideas. Cultural conflict means does not conflict only with language and dialects, music, festivals and celebrations, literature, etc but also contains the rules and condition which are basically related to the different social communities. Society and the social life of human beings are not possible without cultural activities and at the same time culture is not possible without society. Here I like to point out the words from Alexander Grew that "the cultural conflicts occur when the people expected of particular behaviour from the others whose cultural background is not to me" (https://en.m.wickipedia.org/cultural_conflict)

On this geographic vast area people are living either with own native land with particular culture or in the host land with the cultural conflicts and cultural hybridity. When a person migrates from the native land to host land, he is trying to dwell with own culture but somehow he is facing many problems and finally tries to set himself with the culture of host land. But he cannot follow the culture heartily and here he puts himself in hybridity with the mingling both the cultures of given from the mother and adopted one. During the interaction among the various cultural groups, what happens generally, human beings behave as per norms of culture, but at the same time when he crosses the boundary line of culture, he carries with him the cultural roots with strong beliefs and values. For e.g., woman drives a car is common in the American culture, but the same activity in the Arabian culture is not permitted and considered it as an offence. Here the difference in the cultural background cannot be fulfilled up to the expectations and this leads to the cultural conflicts and cultural hybridity. Every individual on the earth tries to survive and living with the own culture which creats the atmosphere of multiculturalism. And as a result multiculturalism is 
also one of the causes behind the cultural conflicts. Whereas the concept of cultural hybridity always trying to cope with homeland and hostland.

\section{Cultural Conflict in Michael Ondaatje's In the Skin of a Lion}

Michael Ondaatje is one of the prestigious literary figure of the Sri Lankan literature who himself suffering from the homesickness and as a result he has poured his own feelings in his diasporic writing. His master piece In the Skin of a Lion (1987) is depicted with the lives of the immigrants and the building construction workers of Bloor Street Viaduct Bridge and a water purification plant. But their hard work and labour does not have any place behind the history of Toronto City. Labours are migrates from their own nation with the particular culture but they are renders as cultural outsider in the host country. According to Linda Hucheon these outsiders are made the paradoxical centre of the novel.Ondaatje has explored the nude reality of the present life style and culture of the Canadian society. Immigrants try to assimilate into the host culture, but the cultural differences among the group do not allow them to become with the host culture. Here Winfried Siemerling points out how these immigrants enter in the world of host land with the multicultural society and their worse condition in the periphery of new language. He writes:

The novel defamiliarizes habitual perceptions of Toronto by superimposing a reconstructed and imagined new world. With the non-English-speaking immigrants of Toronto, Ondaatje follows a whole community that crosses boundaries and borders to another reality and a new language. (Siemerling, 92)

The immigrant workers are arrived in Canada from the different geographical areas Macedonians, Finns, Greeks and Italian workers. They are not aware about the language of the host land and as a result they are playing role as a silent puppet. During the novel we can see that the workers are used to call others by their nationalities like- "Hey Italy! Hey Canada!" (Ondaatje, 135). Rowland Harris- the commissioner of this construction used to exploit the immigrant labours. In fact the labours, tanneries, thieves, prisoners and persons who doing filthy jobs in slaughter houses are the protagonists of Ondaatje and they are depicted as the outsider of the 
Canadian society. The insider of the society like Patrick Lewis and Commissioner Harris, Clara and Alice are also immigrants in their own country. Patrick Lewis is not conscious about his own culture. Novel opens with the scene when Patrick meets with group of people collecting the fire wood. He is presented with the keen observer of the nature and puts himself in the pale green and nameless until 1910. Patrick's father Hazen Lewis was uninterested in the habits of civilization and culture and as a result he could not give the cultural habits to his son. He was make his son busy with the inherent profession of herding and haying the cattle. After a period he tried himself as a dynamiter in the fluorspar mines and trained his son in the same field. But Hazen never taught him how to live a life. Patrick was afraid of cultural life, but finally he left his rural life behind and moved forward with the Toronto.

The depiction of Toronto city in the presence of Lewis Patrick and Nicholas Temelcoff are ample examples of cultural conflict by Ondaatje. City of Toronto make Patrick feel an immigrant in his own culture. Patrick is a man who does not know about the civilised society and culture and now he enters in the highly cultured society. Patrick was only twenty one years old when enters in the city. He started his career with the job of finding out the millionaire Ambrose Small. Cultural conflicts arose when Patrick tries to settle himself among the Macedonians. Patrick starts to work with immigrant workers in tunnel construction under the lake. Dynamiting work is very hard to do and moreover during eight hour shift no one speaks with each other because of each one was belonging from the different culture and cultural conflicts arose here. Patrick lives among the immigrants community of Toronto. Ondaatje has depicted the south-eastern part of the city made up of immigrants. Ondaatje describes it as-

The Southeastern section of the city where he now lived was made up of mostly of immigrants and he walked everywhere not hearing any language he knew deliriously anonymous. The people on the street Macedonians and Bulgarians, where his only mirror. He worked in the tunnels with them. (Ondaatje, 112)

Here Patrick was happy with the immigrants and shares his little ethnic affinity with them. When Patrick tries to buy some fruits for iguana, fruit sellers cannot understand what Patrick means to say. Ondaatje explains this confusion due to the code of language between Patrick and immigrants as-

Four women and a couple of men then circled him trying desperately to leap over the code of languages between them. His obsession 
with vetch had puzzled them. He had gone at one point into the centre of the city, brought some, and returned to the Macedonian to show them what he needed. The following week, a store owner had waved it to him as he came down Eastern Avenue. Vetch was feeee. (Ondaatje, 112-13)

After all the friendship proposal of Patrick was accepted by the Macedonians. And he was invited by them in waterworks gathering. During this celebration there was arranged the puppet show in the silent mode which nicely present the helplessness of immigrants. It reveals the identity crisis and their condition as they are not able to communicate with the new world. The show highlights the plight situation of the immigrants in the host land. Narrator presents this scene in his own dipiction style-
All of the puppets looked stunned. Feet tested air before each exaggerated step was taken on this dangerous new country of the stage. Their customs were a blend of several nations...The human puppet, alien and naïve and gregarious, upset everything. The face in spite of moustache was dark and Serbian pants. (Ondaatje, 116- 17)

Through this puppet show Ondaatje has put forward the situation of immigrants as a puppet in front of authority. In the puppet show narrator portrays the frustration of the immigrants. The show mimics the helplessness of the immigrants. The result of the show was out comes from the cultural conflicts. It also portrays immigration as the cause of cultural conflict within the immigrant community. It also depicts the role of the human puppet performed by Alice Gull, the close friend of Clara in the political gathering brings Patrick to immigrant community. Patrick remembers the condition of dyers when their bodies totally tired and only their head are white. The dyers were mostly immigrants and they had miserable condition as they all arrived at work place in the morning darkness and works till six in the evening. Their work area was without any ventilation and their English names were given by the agents but they were difficult to remember. Patrick was Canadian by birth but he aligns himself due to the lack of language. He was cultural outsider.

Throughout the novel we can see that due to the cultural conflict the out siders were suffering from lot as the police chief Draper has imposed laws against them for public meeting. And if any one speak other than English language, they are sent to the jail. And thus so many immigrants were arrested during the various rallies in High Park. 
Nicholas Temelcoff is also a Macedonian immigrant. He is arrived in Canada in 1914 without passport. He loves his new language and decided to overcome this barrier and to settle in Canada. So he has decided to go to school and to work at nights in another Macedonian bakery.

\section{Conclusion}

As per the critical discussion and the depiction style of Michael Ondaatje, we can justify the novel as- it depicts the plight and miserable condition faced by the immigrants. Insider like Patrick Lewis is also suffering from the same situation. Even though he is belonging from the same culture, he is facing the problem of cultural conflict as he is unknown about the country's culture. The novel also portrays the stricking picture of the cultural clash. There are many themes woven around the immigrants' like- theme of alienation, rootlessness, dislocation etc. The immigrants are the real structurers of the city of Toronto, but their efforts were unrecorded in the city.

\section{Work Cited}

1. Jodha Avinash. Michael Ondaatje's Fiction: Poetics of Exile. New Delhi: Rawat Publication, 2011.

2. Linda Hutcheon, "Ex-Centric" In the Skin of a Lion: A Novel," Michael Ondaatje's, Canadian Literature, 117 summers, 1988.

3. Sophia, M.Sagaya. "Fantasy/Reality: A violent Transformation/Self-Assertion of The Female Hero," An Analysis of Bharati Mukherjee's Wife: Canadian Studies in India (ed.) Dr. K. Balchandran

4. Ondaatje, Michael.In the Skin of a Lion. New York: Vintage Books, 1997.

5. Winfried, Siemerling. "Oral History and the Writing of the Other in Ondaatje's In the Skin of Lion," In Comparative Cultural Studies and Michael Ondaatje's Writing. Ed. Steven Totosy de. Zepetnek, 2005.

\section{Dr Om P Joshi \\ Department of English \\ Bhakta Kavi Narsinh Mehta University, Junagadh Gujarat, India}

